\title{
Antalyalı Athenaeus'un Felsefesinde Ruh (Pneuma) ve Beden İlişkisi
}

\author{
NIHAT DURMAZ \\ Bartın Üniversitesi İslami İlimler Fakültesi \\ ndurmaz@bartin.edu.tr \\ https://orcid.org/0000-0002-9633-2282
}

\begin{abstract}
Öz
Antik Yunan'da ortaya çıkan felsefe, MÖ 4. yüzyıldan MÖ 1. yüzyıla kadarki süreçte pek çok değişime uğrayarak gelişimini devam ettirmiştir. Felsefe, doğadan insana geçerek ilk değişimini, Platon ve Aristoteles tarafından felsefenin genel çerçevesinin çizildiği sistematik dönemle de ikinci değișimini gerçekleștirmiştir. Bu süreçte çizilen genel çerçevenin felsefenin yanında tıp alanını da etkilediği ve bu etkinin MÖ 1. yüzyılda açıç̧a ortaya çıktığı görülür. Bu çalışma, söz konusu dönemde filozof olduğu kadar hekim unvanıyla da tanınan Athenaeus'un ruh/beden düalizminde hangi düşünce okullarını benimsediğini ve ne tür kaynaklardan beslenerek mesleğini icra ettiğini ortaya koymayı amaçlamaktadır. Buna göre Athenaeus'un felsefesini Platon ve Stoacı görüşlerden hareketle açılamanın o dönemin önemli bir tartışma zeminini oluşturan ruh/beden ilişkisini daha anlaşılır kılacağı ifade edilebilir. Nitekim Roma İmparatorluğu'nun kuruluş döneminde hekimler, fizyolojik ve zihinsel olduğu farz edilen pek çok hastalığı psikolojik tedavilerle gidermeye çalışmışlardır. Ayrıca bu anlayıș, bedensel hastalıkların ruhsal durumlarla ilişkili olduğunu göstermesi açısından önemlidir. Hekimlerin psikolojik rahatsızlı̆̆ bulunan hastaları dikkat dağıtıcı egzersizlerle iyileştirme çabaları, böyle bir düşüncenin sonucu olarak okunabilir.
\end{abstract}

Anahtar Kelimeler: Antik Yunan Felsefesi, Antik Yunan Tıbbı, Antalyalı Athenaeus, Pneuma, Ruh, Beden, Diyet.

\section{Soul (Pneuma) and Body Relation in the Philosophy of Athenaeus of Attalia Abstract}

The philosophy that emerged in Ancient Greece has undergone many changes and continued its development. The first change in philosophy was realized by shifting focus from nature to man, and the second change was realized by Plato and Aristotle during the systematic period in which the general framework of philosophy was drawn. It can be said that the general framework drawn during this process influenced the field of medicine as well as philosophy. This influence appeared clearly in the 1st century BC. This study aims to reveal which schools of thought were adopted by Athenaeus, who was also a physician as well as a philosopher, in soul/body dualism and what kind of sources he utilized for practicing his profession. Accordingly, one can state that explaining the philosophy of Athenaeus based on Platonic and Stoic thought makes the relationship between soul and body that constitutes an important basis of discussion of that period more understandable. As a matter of fact, during the foundation period of the 
Roman Empire, physicians tried to cure both mental and physiological diseases by psychological treatments. Furthermore, this understanding is important in terms of showing that physical diseases are also related to mental states. The efforts of physicians to cure patients with psychological disorders through distracting exercises can be read as a result of such a thought.

Keywords: Ancient Greek Philosophy, Ancient Greek Medicine, Athenaeus of Attalia, Pneuma, Soul, Body, Diet.

\section{Giriş}

Galen, MÖ 1. yüzyılın sonlarında Pamfilya'nın Attalia (Antalya, Türkiye) bölgesinde yaşamış olan Athenaeus'un ${ }^{1}$ hem pneumatolojik ${ }^{2}$ tıp okulunun kurucusu hem de Stoacı filozof Posidonius'un (MÖ 135-51) ${ }^{3}$ öğrencisi olduğunu aktarır. ${ }^{4}$ Buna karşın Vivian Nutton (d.1943), Galen'in vurgulamak istediği hocanın Apamealı bilim insanı Posidonius olması halinde Athenaeus'un MÖ 1. yüzyılda yaşamış olacağını ancak Pliny ya da Celsus'un Athenaeus ve onun kurucusu olduğu pneumatist okuldan hiç bahsetmediği için filozofun MS 1. yüzyılda yaşamış olmasının kuvvetle muhtemel olduğunu ileri sürer. Bu iddia, Athenaeus'un Posidonius'un öğrencisi değil de onun felsefesini iyi derecede anlamış ve Roma İmparatorluğu'nun kuruluş döneminde yaşamış bir filozof ve hekim olduğunu göstermektedir. Galen, bu

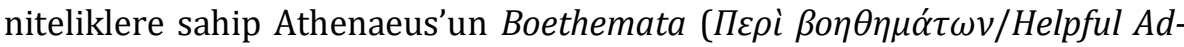
vice) adında önemli bir eser kaleme aldığını ancak bunun kendi zamanına ulaşmadığını söyler. Ona göre bu kitaplarda dönemin felsefe ve tıp alanındaki en genel tartışmalarını işleyen Athenaeus, tıp alanına dair görüşleri

\footnotetext{
${ }^{1} \mathrm{Bu}$ çalışmamızda vurgulanması gereken önemli bir husus, Antalyalı Athenaeus'un MS 2-3. yüzyıllar arasında yaşamış olan Mısırlı Athenaeus ile karıştırılma olasılığıdır. Nitekim çalışmamıza konu olan Athenaeus'un hem hayatı hem de düşüncelerine dair çok sınırlı bilgi olmasına rağmen Mısırlı Athenaeus'un hem hayatı hem de eserleri ile ilgili nispeten daha geniș malumat bulunmaktadır. Bu yüzden çalıșmamızda Antalyalı Athenaeus'un felsefi görüșlerini elimize ulaşan kaynaklardan hareketle okuyucuya aktarmaya çalıșacağız.

2 Pneumatoloji, ruh ve bedenden teșekkül eden insanın ruhsal yönünü nefes anlamına gelen ve bedene bağımlı olan pneuma kavramıyla açıklayan bir yaklaşımdır. Dagobert D. Runes, The Dictionary of Philosophy (New York: Philosophical Library, 1942), s.241. Bu düșünce, felsefe tarihi açısından Anaksimenes'e kadar geriye götürülebilir. Antony Preus, Historical Dictionary of Ancient Greek Philosophy (Lanham: The Scarecrow Press, 2007), s.184.

3 Posidonius, Suriye'de yaşamış olan Stoacı bir filozoftur. 0, Atina'da Panaetius'dan ders aldıktan sonra Roma İmparatorluğunun sınırlarını da aşan geniş bir coğrafyayı tanıma imkanı bulmuştur. Pek çok alanda yazılmıș eserleri bulunan filozofun her ne kadar çok az fragmanı günümüze ulașsa da bilimsel, edebi, tarihi ve coğrafi alanlarda çalışmalar yaptığı bilinmektedir. Onun felsefi önemi ise Platon ile Aristoteles felsefelerini Stoacı bir sistem içerisinde birleştirmeyi önemli ölçüde başarmış olmasıdır. Preus, Historical Dictionary of Ancient Greek Philosophy, ss.217-218.

${ }^{4}$ Galen, Selected Works, ed. Peter N. Singer (New York: Oxford University Press, 1997), s.208; Sean Coughlin, "Athenaeus of Attalia on the Psychological Causes of Bodily Health," Chiara Thumiger and Peter Singer (ed.), Mental Illness in Ancient Medicine (Leiden \& Boston: Brill, 2018) içinde, s.116.
} 
aktarırken göstermiş olduğu objektifliği felsefi düşüncelerde ortaya koyamamıştır. ${ }^{5}$ Buna ilaveten Athenaeus'un tıp alanındaki çalışmalarını daha ileriye taşıyan Spartalı Claudius Agathinus ile Apamealı Archigenes adlı iki öğrencisi olduğu da belirtilmelidir. ${ }^{6}$

Athenaeus, zihinsel hastalıklar, diyet ve embriyoloji ile ilgilenerek hekim kimliğini, nedensellik ve ruh/beden düalizmini ele alarak da felsefi yönünü geliştirir. Bu araştırmalarda zihinsel hastalıkların ortaya çıkışını bedensel niteliklerin iyi karışmamasına bağlayan Athenaeus, insanda oluşan uyuşukluğun (letarji) ${ }^{7}$ hem üzüntü hem de anormal bir akıldan kaynaklı olduğunu iddia eder. Diyet hakkında ise filozof, dört yazı kaleme almıştır. Nitekim Oribasius'un (?) aktardığına göre Athenaeus, bu metinlerde insan sağlığının ruhsal ve bedensel eğilimlere bağlı olduğunu ve sağlığın her iki alana dair egzersizlerle korunabileceğini vurgular. Buna göre bedensel egzersizler yeme, içme, yıkanma ve uyuma şeklinde kategorize edilirken ruhsal egzersizler düşünme, eğitim ve otokontrol olarak ifade edilir. Bu noktada bedensel egzersizlerin filozofun hekim yönüne, ruhsal egzersizlerin de felsefi yönüne gönderme yaptığı fark edilmelidir. Buna ilaveten ruh ve beden arasındaki ilişkiyi diyet üzerinden ele alarak her ikisini de önemseyen Athenaeus'un Platon'dan Stoacılara kadarki süreçte daima tartışılagelen ruh/beden düalizmini tıp ${ }^{8}$ alanına da dahil ettiği görülür. ${ }^{9}$

\footnotetext{
${ }^{5}$ Athenaeus'un herhangi bir eseri günümüze ulaşmadığından Galen'in iddiasının objektif bir zeminde tartışılması mümkün değildir. Bu nedenle Galen'in iddiasının pekala sübjektif bir düşüncenin mahsulü olma ihtimali de mümkündür.

${ }^{6}$ Vivian Nutton, Ancient Medicine (Londra \& New York: Routledge, 2004), ss.202-203.

${ }^{7}$ Antik Yunan'da delilik (madness) ile hezeyan (delirium) arasındaki ilişki pek çok filozof tarafından incelenmiş ve biri diğerinin alt dalı olacak şekilde iki görüş ortaya çıkmıştır. Bunlardan ilki, deliliği hezeyanın bir türü olarak gören anlayıștır. Asclepiades'in başını çektiği bu anlayıș, her şeyin ateşsiz ve kronik olması halinde deliliğin ortaya çıkacağını savunur. Buna karşın ikinci görüş, hezeyanı deliliğin bir türü kabul eden Stoacı yaklaşımdır. Bu yaklaşım, her iki hastalığı da salt bedensel açıdan ele alan birinci anlayıștan farklı olarak söz konusu hastalıkları hem ruhsal hem de bedensel yönleriyle inceler. Her iki yaklaşımı da benimseyen Athenaeus'un aksine o dönemde pek çok hekim, uyuşukluğun deliliğe kadar uzanacak bir niteliği bilinmediği için herhangi bir görüşe sahip değildir. Hatta Caelius'un Athenaeus'a atfettiği düşüncelerin pek açık olmayışından ötürü Coughlin, Athenaeus'un söz konusu hastalık hakkında ne söylediğinin nesnel bir açıdan tespitinin zor olduğunu ileri sürer. Bu noktada açıkça vurgulanacak husus, Athenaeus ile diğer düșünürlerin "uyușukluk" ve "delilik" arasında kesin bir ayrım yaptıklarıdır. Galen, her ne kadar pneumatistlerin Stoacı düşünceden etkilendiğini ifade etse de pneumatistlerin Stoacıların felsefi görüşlerini almalarına rağmen tıbbi görüșlerini benimsememeleri de ihtimal dahilindedir. Buna karşın Athenaeus'un "uyuşukluğu" ve "deliliği" Stoacı zaviyeden ele almasının da muhtemel olduğu unutulmamalıdır. Bkz. Coughlin, "Athenaeus of Attalia," ss.114-116.

${ }^{8}$ Athenaeus'un tıp ilmini hastalık, sağlı ve nötr durumlar (neutral things) şeklinde bir sınırlama üzerinden tanımladığı ileri sürülebilir. Yine de böyle bir ayrımın Athenaeus'dan önce de Herophilus gibi- var olduğu unutulmamalıdır. Ancak Athenaeus'un tıp ilmini fizyoloji, patoloji, diyet, tedavi bilimi ve tıbbi malzemeler şeklinde beșe ayırması, Galen ve Herophilus'tan ayrı bir
} 


\section{Athenaeus'un Felsefesinde Ruh (Pneuma) Kavramı}

Athenaeus'un felsefesinde önemli bir yerde bulunan pneuma kavramı, Hipokrates'in yaşamış olduğu MÖ 5. yüzyıldan itibaren ruh/beden düalizminde belirleyici bir rol oynamıștır. Bu durum, özellikle metodoloji ile epistemoloji arasında var olan temel tartışmalarda daha belirgin bir hale dönüşmüştür. Bu tartışmalarda temel problem, kavramsallaştırılan herhangi bir kelimenin terminolojik açıdan farklı bir anlama sahip olmasından kaynaklıdır. Sözgelimi doğa, neden, sembol (sign), işaret (indication), kanıt ve yetenek (faculty) bu kavramlardan birkaçını oluşturmaktadır. Buna ilaveten nedensellik, gözlem, benzerlik ve deneyimsellik açısından da anlamsal bir farklılı̆ı̆ ortaya çıktığı söylenebilir. Hellenistik dönemde tıpta uzman düşünürlerin (Heraphilus ve Erasistratus gibi) pneuma kavramını insanı mekanik bir tarzda açıklayan meslektaşlarının aksine teleolojik açıdan ele aldıkları görülür. İnsanın teleolojik yönüne yapılan bu vurgu, bilginin doğasına dair empirist, dogmatik ve metodist yaklaşımların oluşmasına sebebiyet vermiştir. Buna göre bilginin doğası, Galen ${ }^{10}$ ve Caelius Aurelianus tarafından bilim felsefesi ile mantık alanına dahil edilirken Roma İmparatorluğunun ilk döneminde başta tıp ve felsefe olmak üzere pek çok alanda nedensellik ${ }^{11}$ ve çıkarım gibi problemler ortaya çıkmıştır. Teorik ile kavramsal olanın ayrımını ifade eden bu problemler, Athenaeus tarafından pneumatik açıdan ele alınmıştır. ${ }^{12}$

Hipokrates'den Athenaeus'a kadarki süreçte pneuma kavramının zihin/beden arasındaki uçuruma köprü olacağı ümidiyle çoğu filozof tarafından kullanıldığı iddia edilebilir. Sözgelimi Galen, pneumatik yaklaşımdan farklı olarak bu kavramı, hem patolojik ve fizyolojik çalışmalarıyla birleş-

\footnotetext{
özgünlüğe sahip olduğunu göstermektedir. Bkz. Herophilus, The Art of Medicine in Early Alexandria, ed. Heinrich von Staden (New York: Cambridge University Press, 1989), ss.107-108.

${ }^{9}$ Coughlin, "Athenaeus of Attalia," ss.109-113.

10 Roma İmparatorluğunun ilk döneminde empirist ve metodist düşünceler (en ünlüleri Trallesli Thessalus'tur) ile Hipokrates ve onun düșüncelerine paralel hareket eden Galen'in düșünceleri etkili olmuştur. Özellikle Galen'in düşüncesi, tıp alanında daha sonra ortaya çıkan dogmatik yönelimlere engel teşkil etmiştir. Ancak tarihsel bilgiler, Galen'in tıbbi metodolojisini oluștururken hem hocalarından hem de seleflerinden etkilendiğini göstermiştir. Galen'in yanında en ciddi muhalefetin insan sağlığı ile hastalıklarını düzenleyen gücün pneuma ya da ruh (spirit) olduğunu iddia eden Pneumatistlerden geldiği ifade edilmelidir. Bkz. Nutton, Ancient Medicine, s.202.

${ }_{11}$ Athenaeus'un nedensellik hakkındaki görüşleri için bkz. Robert James Hankinson, "Evidence, Externality and Antecedence: Inquiries into Later Greek Causal Concepts," Phronesis 32:1 (1987), ss.80-100.

${ }^{12}$ Philip J. van der Eijk, Medicine and Philosophy in Classical Antiquity (New York: Cambridge University Press, 2005), ss.12-13.
} 
tirmiş hem de sempatik sinir sisteminde ${ }^{13}$ etkin bir hale getirmiştir. ${ }^{14}$ Ancak günümüzdeki nörofizyoloji bașta olmak üzere pek çok bilim, yapılan araştırmalara rağmen zihin/beden arasındaki ayrımı kapatmaya güç yetirememiştir. Örneğin bedenimizdeki hava ile dışarıdaki havanın hem nasıl bir doğaya sahip olduğu hem de ikisi arasında nasıl bir ilişkinin tesis edileceği tartışmalı hususlar olarak kalmaya devam etmektedir. Buna ilaveten hem pneuma $^{15}$ ve air gibi birçok kavramın aynı anlamda kullanılması hem de aer, aither, pneuma, phusa ve anemas gibi kavramların çok yakın anlama sahip olmaları, söz konusu karışıklı̆̆ı daha da artırmaktadır. Bunlardan anemos rüzgara ait bir özellik olmanın yanında Hesiodos'un Theogany adlı eserinde bir tanrıya aşık olan Astraios adlı tanrıçanın durumuna üzülen bir rüzgarın adıdır. ${ }^{16}$

Llyord, phusa kavramının yukarıda ifade edilen kavramlardan daha açık bir anlama sahip olduğunu, phusao kökünden gelen bu kavramın akciğer ve bir volkan krateri anlamına geldiğini iddia eder. Pneo kavramı ise en genel anlamda hava ya da nefes solumak şeklinde tanımlanır. Pneuma ise sadece ruha uzanan bir nefes ve esinti şeklinde tarif edilir. Bu kavram, Kutsal Ruh yerine de kullanılmakta ise de genellikle filozoflar tarafından ruh/beden düalizmini aşma teşebbüslerinde müracaat edilen bir kavramdır. Aither ve aer kavramları birbirinden ayrı ele alındığında aerin doğa filozofları tarafından arkhe anlayışlarında müracaat ettikleri bir kavram olduğu veya dört elementten biri (hava) yerine kullanıldığı görülür. Gerçi Empedokles'in aither kavramını da hava yerine kullandığı bilinen bir husustur. Ancak Aristoteles'in aither kavramını beşinci element kabul etmesi, bu kavramın önemini ortaya koyması açısından önemlidir. Bu beşinci element, ona göre ne soğuk ne de sıcak ne kuru ne de yaş bir özelliktedir. Lloyd, Aristoteles'teki aither kavramı ile Stoacılarda pneumanın bulunduğu yerin aynı olduğunu

\footnotetext{
${ }^{13}$ Sempatik sinir sistemi, "vücutta üretilen enerjinin tüketilmesine neden olan katabolik aktivitelerin harekete geçmesini sağlayan" bir yapıyı ifade eder. Gülseren Akyüz ve Merve Akdeniz Leblebiciler, "Otonom Sinir Sistemi Anatomisi ve Değerlendirilmesi," Türkiye Fiziksel Tip ve Rehabilitasyon Dergisi 58:1 (2012), s.2.

${ }^{14}$ Ian Johnston, Galen: On Diseases and Symptoms (New York: Cambridge University Press, 2006), s.19.

${ }^{15}$ Athenaeus, ruhu pneuma ya da nefes (breath) ile aynı anlamda kullanır. Bu durum, filozofun ruhu bedene bağıml, bedenin tamamına yayılmış bir maddi töz olarak kabul ettiğini gösterir. Zira Athenaeus felsefesinde pneuma kavramının insanın bedensel gelișimi ile sürekliliğinden sorumlu olan doğuştan bir ısı olarak tanımlandığı ifade edilebilir. Eğer böyle bir ısının egzersizlerle artırılması sağlanırsa bedenin ısısının da buna paralel olarak artacağı görülür. Coughlin, "Athenaeus of Attalia," ss.120-121.

${ }^{16}$ Geoffrey Lloyd, "Pneuma between Body and Soul," The Journal of the Royal Anthropological Institute 13 (2007), ss.135-136.
} 
iddia eder. Buna göre Athenaeus başta olmak üzere Stoacıların bu kavramı dünyanın devamlılığını vurgulamak için kullandıkları ileri sürülebilir. Hatta onlar, söz konusu kavramı physcial ve psychic olarak ikiye ayırmışlardır. Pneuma'nın Hipokrates'teki kullanımına bakıldığında onun bütün hastalıkları nefese (breath/phusa) bağımlı bir şekilde tasvir ettiği görülür. ${ }^{17} \mathrm{Bu}$ düşünce, bedene ait bir özellik olan pneumayı phusa kavramıyla, bedenden dışarıdaki havayı da aer kavramıyla ifade ederek ilkini cins, ikincisini de cinsin türleri şeklinde sınırlandıran bir anlayışı dillendirir. ${ }^{18}$

\section{Athenaeus'un Felsefesinde Ruh/Beden İlişkisi}

Athenaeus'un ruh/beden düalizminde takındığı tavrın nasıl bir sürecin mahsulü olduğunu tespit etmek filozofun görüşlerini daha anlaşılır kllacağı için söz konusu düalizmin Antik Yunan'dan itibaren genel çerçevesi ortaya konulmaya çalışılacaktır. Hatırlanacağı üzere mithosdan (myth) logosa dönüşümü sağlayarak felsefenin doğuşuna neden olan Antik Yunan felsefesi ${ }^{19}$ ruh/beden, görünüş/gerçeklik gibi pek çok dikotomiyi ortaya çıkarmıştır. Bu dönemde ruh/beden düalizmi ile ilgili temelde üç anlayışın hakim olduğu görülür. Bunlardan ilki her ikisini ayrı varlık alanı olarak kabul eden ${ }^{20}$ Platoncu felsefedir. Bu anlayıșın temel çlkmazı, her ikisi arasındaki ilișkinin nasıl olduğuna dair herhangi bir açılama getirememesidir. İkinci anlayış, ruh ve bedeni aynı varlığın farklı yönleri olarak kabul eden Aristotelesçi yaklaşımdır. Bu yaklaşımın temel çıkmazı ise canlı ve cansız varlıkların nasıl birbirinden ayrıldığı veya cansız varlıkların niye var olduğu sorusuna cevap

\footnotetext{
17 Hummayı (fevers) genel ve özel olarak ikiye ayıran Hipokrates, genel kısma ait olan Veba'nın pneumadan kaynaklandığını ileri sürer. Ona göre özel kısım ise insanın uyguladığı diyetle yakından ilişkilidir. Buna göre insanın yeme ve içme eylemlerinde pneumayı yuttuğu, daha sonra da geğirmeyle çıkardığı vurgulanır. Nitekim Hipokrates'in tedavi için gittiği yerlerin rüzgar durumuna, yeme/içme alış̧anlıklarına, yaşam tarzlarına dikkat ettiği ve bu özelliklere göre tedaviler önerdiği bilinen bir husustur. Sözgelimi güney rüzgarları sağırlığa, görme bulanıklığına, baș ağrısına neden olurken kuzey rüzgarları öksürüğe, boğaz ağrısına ve kabızlığa sebebiyet vermektedir. Lloyd, "Pneuma between Body and Soul," s.138.

${ }^{18}$ Lloyd, "Pneuma between Body and Soul," ss.137-138.

${ }^{19}$ Ahmet Arslan, İlkçağ Felsefesi Tarihi 1: Sokrates Öncesi Yunan Felsefesi (İstanbul: İstanbul Bilgi Üniversitesi Yayınları, 2006), s.75.

20 Platon, Philebos adlı diyalogunda insanda var olan ruh/beden arasındaki ayrımın evrendeki ayrımdan kaynaklı olduğunu, hatta insani ruhun evrensel ruhtan beslendiğini iddia eder. Nitekim o, bu hususu şöyle ifade eder: "Sana şunu soruyorum: Acaba evrenin vücudu mu bizim vücudumuzu besler, yoksa bizim vücudumuz mu ona gidasını verir ve söylediğimiz gibi vücudun teșekkülüne giren șeyi ondan mı almıștır ve almaktadır? (Bu noktada) vücudumuzun bir ruhu vardır demez miyiz? (Vardır, deriz) evrenin vücudunda ruh olmasaydı, ondan bizden olan șeylerden her bakımdan güzelleri bulunmasaydı, vücudumuz ruhunu nereden alırdı, ey Protarkhos'um? (Hiçbir yerden alamazdı.) Sonlu, sonsuz bu ikisinin karışığı ve her şeyde dördüncü cins olarak bulunan sebep diye saydığımız bu dört cinsten, vücutlarımıza ruh veren, bunları işleten, hastalandıkları zaman iyi eden, daha bin türlü terkip meydana getiren ve bunları onaran sebebi, șüphesiz tam ve som bir bilgelik sayamayız." Platon, Philebos, terc. S. Esat Siyavuşgil (İstanbul: MEB Yayınları, 1997), ss.47-48.
} 
verememesidir. Athenaeus'un da etkisinde kaldığı üçüncü ve son anlayış, bedenin bazı durumlarda canl, bazı durumlarda cansız olduğunu ifade ederek problemin farklı bir alana taşınmasını sağlayan Stoacı görüştür. ${ }^{21}$

Antik Yunan'da böylesi bir değişimi anlamlı kılan sürece daha yakından bakıldığında ruh/beden düalizminde Platon'un ruhu hem ölümsüz ${ }^{22}$ kabul ettiği hem de bedenden bağımsız bir yerde konumlandırdığı görülür. Nitekim o, Phaidon adlı diyalogunda ruh/beden arasında keskin bir ayrımın var olduğunu, ruhun bölünemeyen, bedenin ise bölünebilen bir yapıyı temsil ettiğini söyler. Buna göre bölünemeyen ruh sabit ve değişmez bir karakteri yansıtmasına rağmen bedenin sürekli değişen bir yapıda olduğu ifade edilebilir. ${ }^{23}$

Platon'un felsefesinde ruh, her ne kadar bedenle ilişkisinden dolayı mertebe olarak aşağı bir seviyeye gerilese de son tahlilde bedenden ayrı bir ontolojik karaktere sahip olduğundan daima üstünlügünü muhafaza eder. Ruhun üstünlügünü sağlayan nitelikleri ise basit bir cevher olmasıdır. $\mathrm{Bu}$ özellik, bileşik bir yapıya sahip olan bedenin dağılıp birleşmesinden ziyade ruhun her daim ayrı kalmasını zorunlu kılar. Bu yüzden Platon'un hem ölümsüz hem de sabit kalan ruhu bedenden üstün kabul ederek tasarruf yetkisini ruhtan yana kullanması anlaşılır bir husustur. Platon felsefesinde insanın bedensel ihtiyaçlarını minimuma indirerek ruhsal yönlerini aşikar kılması asli bir vazifesi olarak ifade edilir. Bu vazifenin nihayetinde, diğer ifadeyle insanın ölümünden sonra ruhun bedenden ayrılarak yakın bir ilişki içerisinde olduğu "idealar" alemine geri döneceği ileri sürülür. ${ }^{24}$

Ruh/beden düalizminde Platon, ahlaki açıdan da ruhu merkeze alan bir yapıyı dillendirir. Nitekim o, mutluluğa (eudaimonia) iştiha, tin ve akıldan oluşan ruhun kolektif bir ilişkisiyle ulaşılacağını iddia eder. Onun beslenme ve üreme gibi faaliyetleri bedenden ziyade ruhun bir niteliği olarak görme-

\footnotetext{
${ }^{21}$ Lloyd, "Pneuma between Body and Soul," s.144.

${ }^{22}$ Bilgiyi hatırlama üzerinden temellendiren Platon, bu görüşü ruhun ölümsüzlügüne delil olarak kabul eder. Hatırlama ile ruhun ölümsüzlüğü arasındaki ilișki için bkz. Platon, Phaidon, terc. Ahmet Cevizci (Ankara: Gündoğan Yayınları, 1995), ss.27-43.

${ }^{23}$ Platon, ruhu bedenden üstün gördüğü için bedenin ruhtan sonra yaratıldığını iddia eder. 0 , ruhun yaratılmasını ise şöyle ifade eder: "Bölünmez ve her zaman aynı kalan tözle cisimlerde bulunan ve bölünebilen tözü birleștirerek bir üçüncü ortalama töz vücuda getirdi, bu tözde hem aynı kalan hem de öteki töz vardı. Böylece onu bölünmez töz ile cisimlerin bölünebilen tözü ortasına koydu. Sonra aynı kalanı öteki cevherin güç birleșen özüyle zorla ahenkleștirerek üçünü birleștirip tek bir biçime soktu. İlk ikincisini üçüncü ile karıştırıp üçünden birkaç bütün meydana getirince, onu uygun düşecek sayıda parçalara ayırdı; bu parçaların her biri aynı kalanla ötekinin ve üçüncü tözün bir karışması idi." Platon, Timaios, terc. Furkan Akderin (İstanbul: Say Yayınları, 2015), s.37. Platon'un ruh/beden ilișkisine dair ayrıntılı bilgi için bkz. Platon, Phaidon, ss.45-77.

${ }^{24}$ Ahmet Cevizci, Metafiziğe Giriș (İstanbul: Paradigma Yayınları, 2001), ss.37-38.
} 
si, ruh/beden düalizminde bütün eylemleri ruhsal bir yapıdan hareketle temellendirdiğini ortaya koyar. Benzer bir durumun Aristoteles için de geçerli olduğu söylenebilir. Nitekim Aristoteles, iștiha ve tini, ruhun akıldışı bir yönü olarak tanımlar ve mutluluğa ulaşmak için bedene ihtiyaç duymaz.

Aristoteles, Ruh Üzerine adlı eserinde ruh/beden düalizminde ruhu maddeden ziyade bir form olarak kabul eder. Ona göre ruhun maddesi bedendir ve her ikisi arasındaki ilişki, göz ile görme fiili arasındaki münasebetten hareketle anlaşlabilir. Bu düşünce, ruh ile bedeni birbirinden bağımsız bir şekilde kabul eden Platoncu görüşten farklılaşarak ruhun bedenden ayrı bir yaşamının olamayacağını ortaya koyar. Bu yüzden Aristoteles felsefesinde ruhun ölümsüzlüğüne dair bir inancın olmadığı söylenebilir. Bunun yerine ruh/beden ilişkisinin madde/form münasebeti üzerinden açıklandığı görülür. Nitekim o, bu hususu şöyle ifade eder:

Doğal cisimlerden bazıları canlı ve diğerleri cansızdır; "hayat"tan beslenme, büyüme ve yaşlanma olgusunu anlamaktayız. Buradan şöyle bir sonuç çıkar: Her doğal canlı cismin bir tözü, bileşik töz anlamında tözü olacaktır. Ve bundan başka canlıda, belli bir niteliği olan bir cisim, yani hayata sahip bir beden söz konusu olduğundan, beden ruha özdeş olmayacaktır; çünkü canlı beden, bir süjenin bir yüklemi değil; fakat daha çok, bizzat dayanak ve maddedir. Ardından ruh, zorunlu olarak tözdür; bu, şu anlamdadır: Ruh, bilkuvve (güç halinde) hayata sahip doğal cismin biçimidir. Fakat biçimsel töz entelekheia'dır (yetkin fiil); o halde ruh, bu tür bir cismin entelekheiası'dır. ${ }^{25}$

Shields, Aristoteles'in ruh/beden ilişkisine dair görüşlerini şöyle bir örüntü üzerinden eleștirir: Eğer maddenin zorunlu olarak form tarafından biçimlendirildiği kabul edilirse, bedenin bir ruha büründüğü söylenebilir. Böylelikle ruhunu yitirmiş bir beden ile normal bir bedenin aynı anlama geleceği ifade edilebilir. Bu yüzden Shields'e göre Aristoteles'in ruh/beden münasebetine dair iddiası tutarsızdır. ${ }^{26}$

Stoacılar, ruh/beden ilişkisi konusunda Platon ve Aristoteles'ten ziyade doğa filozoflarına daha yakın bir görüş ortaya koymuşlardır. Nitekim Marcus Aurelius (ö.180), Düşünceler adlı eserinde zamanın akışı içerisinde her şeyde olduğu gibi ruh ve bedende de bir değişimin olduğunu iddia eder. Ona göre bu değişim, ruhta kendisini bir karmakarışıklık ve telaş içerisinde gösterirken bedende bozulma ve çürümeye sebep olur. Bu durum, ruhun hayal

\footnotetext{
25 Aristoteles, Ruh Üzerine, terc. Zeki Özcan (Ankara: Sentez Yayınları, 2014), ss.70-71.

${ }^{26}$ Christopher John Shields, Aristotle (New York: Routledge, 2007), s.292.
} 
ve kuruntudan, bedenin ise bir nehir gibi sürekli akıştan beslendiğini ortaya koyar. ${ }^{27}$

Aurelius'un da içerisinde bulunduğu Stoacı düşünceye göre aktif ve pasif olmak üzere iki temel ilke bulunur. Bu ilkelerden pasif olan, tözün ya da maddenin niteliksel olarak daha az olduğu bir duruma işaret ederken aktif yön tanrl, akıl, kader, ruh ya da pneuma ile ilgili hususu temsil eder. Her ikisini de bedensel nitelikte kabul eden Stoacllar, pneumada phusis ve psucheyi veyahut ruh ile bedeni birlikte ele alarak dıştan gelen herhangi bir etkiyi ortadan kaldırırlar. Doğayı kendi içerisinde aktif bir yapıya dönüştüren bu anlayış, doğanın her tarafına yayılan şeyin pneuma olduğunu öne sürer. Bu iddianın canlı ve cansız varlıklar arasında kesin bir ayrım yapmadığı ve her iki varlık alanını pneuma üzerinden temellendirdiği fark edilmelidir. Felsefe alanıyla sınırlı kalan bu düşünce, Athenaeus ile beraber tıp alanına da uyarlanarak daha ileriye taşınmıştır. Nitekim Athenaeus'un hastalık ve sağlıkta pneumayı hem belirleyici hem de açılayıcı bir etken olarak görmesi, bu gelişimin bir mahsulü olarak okunabilir. ${ }^{28}$ Hatta Athenaeus'un Antik Yunan felsefesinin son dönemlerinde özellikle tıp alanında etkili olan Pneumatik Okulu ${ }^{29}$ böylesi bir ilişkiyi ortaya koymak için kurduğu ileri sürülebilir. Ancak Llyord, Athenaeus'un bu ilişkiyi kurarken nedensellik teorisini Stoacılardan, pneuma ile ilgili görüşlerini Bizanslı Philo'dan ve havaya dair düşüncelerini İskenderiyeli Hero'dan aldığını iddia eder. Bu iddia, Athenaeus'un fizyolojik süreçleri mekanik açıdan tedavi eden çalışmalardan haberdar olduğunu da ortaya koymaktadır. ${ }^{30}$

O halde Athenaeus'un Platon ile Stoacıların ruh ve beden düşüncelerinden etkilendiği ancak son tahlilde bedenin merkezde olduğu radikal bir düalizmde karar kıldığı görülür. Nitekim o, Platon'un Timaeus adlı eserinde diyet ile ilgili yapmış olduğu ayrıma sadık kalmasına rağmen ruhun ölümsüzlügünü kabul etmeyerek kendi düşüncesini oluşturmuştur. Daha açık ifadeyle Athenaeus'un ruhsal ve bedensel egzersizleri aksatmadan yapan kişinin yaşlılıkta da sağlıklı olacağını belirtmesi, beden ile ruhunu dengede tutan kişiyi sağlıklı insan olarak tanımlayan Platon'un görüşlerine paralel

\footnotetext{
27 Marcus Aurelius, Kendime Düşünceler, terc. Ceyda Eskin (İstanbul: Oda Yayınları, 2009), ss.18-19. ${ }^{28}$ Julius Rocca, Galen on the Brain: Anatomical Knowledge and Physiological Speculation in the Second Century AD (Leiden \& Boston: Brill, 2003), s.63.

${ }^{29}$ Herophilus, tıbbın bilimsel bir zemin üzerine inşa edilmesinde pneumatik okulun önemli bir yerde bulunduğunu iddia eder. Athenaeus'un tıp ilmini sentetik bilgi çerçevesinde sistematize etmesinin böyle bir iddiaya kaynaklık teşkil ettiği ifade edilebilir. Herophilus, The Art of Medicine in Early Alexandria, s.106.

${ }^{30}$ Lloyd, "Pneuma between Body and Soul," s.142.
} 
hareket ettiğini gösterir. Ancak Platon'un ruh ve bedenin sağlığını içimizde var olan ilahi yönün canlılığı için gerekli gördüğü yerde o, bu ilişkiyi daha çok bedensel bir tavra yönelerek ifade etmeyi tercih eder. Böyle bir tercih, insanın fayda/zarar denkleminde her ne kadar psikolojik bir yönelime sahip olsa da temelde faydalı olanın bedensel egzersizler üzerinden tanımlandığını ifşa eder. Sözgelimi Athenaeus, çocuğun ${ }^{31}$ bedensel gelişimi için ruhsal açıdan güvenli bir ortamın tesisini oldukça önemser. Bu düşüncede çocuk, ruhsal ve bedensel olarak hem yoğun zihinsel düşüncelerden hem de bedensel aktivitelerden uzak tutulursa, gelişiminin daha hızlı olacağı varsayılır. ${ }^{32} \mathrm{Bu}$ durum, Athenaeus'un psikolojiden yola çıkarak bedende nihayet bulduğu bir egzersiz yolunu takip ettiğini ortaya çıarır. Böyle bir çıkarımın ahlaki bir erdemin kazanılmasında önemli bir yerde bulunan ruhsal gelişimin fizyolojik bir karaktere indirgenmesi anlamına geldiği unutulmamalıdır. Nitekim Athenaeus, özellikle diyet konusunda psikolojik açıdan ele alınan ruha dair herhangi bir söylem geliştirmez, buna karşın konuyu bedensel egzersizler üzerinden irdeler. ${ }^{33}$

Nutton, Athenaeus felsefesinin Stoacı düşüncenin yanında Helenistik dogmatizm ile Hipokrates'in düşüncelerinden de izler taşıdığını ileri sürer. Ona göre böyle bir sentezi gerçekleştiren Athenaeus, sıcak/soğuk ve islak/kuru şeklindeki dörtlü elementin pneuma tarafından bir araya getirildiğini savunarak atomcu görüşleri reddeder. Bu durum, insan vücudunun canlılığını tesis eden pneumanın evrenin tamamına nüfuz eden canlılığın da kaynağı olduğunu gösterir. Zira insan vücudundaki pneumanın değişime uğraması, söz konusu dört özelliğin oranlarının değişmesine neden olmakta ve hastalık da böyle bir değişimden dolayı ortaya çıkmaktadır. ${ }^{34}$ Kalbin

\footnotetext{
${ }^{31}$ Athenaeus, çocuk sahibi olmak isteyen bireylerin ruhsal açıdan sakin ve huzurlu, bedensel açıdan da sağlıklı bir duruma gelmeleri halinde isteklerinin daha kolay bir șekilde gerçekleșeceğini iddia eder. Ancak çocuğun zihinsel anlamda sağlıklı veya hasta olmasında ebeveynin psikolojisinin etkili olmadığını ilave eder. Coughlin, "Athenaeus of Attalia," s.129.

${ }^{32}$ Athenaeus, insanın gençlik döneminde ruhen ve bedenen yoğun bir egzersizin yapılmasını önerir. Bu dönemde arzu yoğun bir hale geldiği için böyle bir önlemin alınması, bireyin ruhen ve bedenen büyük bir tahribata uğramasını engeller. Bu husus, bedensel açıdan daha düzenli ve sağlıklı bir sürece tabi olarak sağlıklı çocuklara sahip olan insanın doğurganlığını da etkiler. Coughlin, "Athenaeus of Attalia," ss.110-111.

${ }^{33}$ Coughlin, "Athenaeus of Attalia," s.110.

${ }^{34}$ Hastalık ve sağlığı beşinci element kabul ettiği pneumaya bağlayan Athenaeus, her hastalıkta yapışkan (cohesive), önceki (prior) ve doğrudan (immediate) olmak üzere üç tarz sebepten bahseder. Doğrudan sebepler, işlevine bakılmaksızın haricî alemden hareketle bedende bazı değişiklikler ortaya çıkarmaya yarar. Önceki sebepler, herhangi bir hastalığa sahip olmasına dikkat edilmeden bedende oluşan durum olarak tanımlanır. Herhangi bir aracıya bağlı olmaksızın doğrudan elde edilen yapış̧an sebepler ise bedende hem dışsal hem de içsel etkenlerden hareketle oluşur. Johnston, Galen: On Diseases and Symptoms, s.101.
} 
çalışması ise kendisinde doğuştan var olan ısı ile akciğerlerin dışarıdan aldığı havanın pneuma tarafından soğutulması arasındaki ilişkiyle mümkün olmaktadır. Bu nedenle Athenaeus, bedenin sağlıklı bir yaşam sürmesi için gerekli olan pneumanın yaşadığı çevreden maruz kaldığı doğa olaylarına kadar pek çok husustan etkilendiğini öne sürer. Böylesi bir etki, filozofun embriyolojiden diyete, nabzı değerlendirmeden sağlıklı su kaynaklarına kadar pek çok konuyla ilgilenmesine neden olmuştur. ${ }^{35}$ Ruhu pneuma ya da nefes (breath) ile aynı anlamda kullanan Athenaeus'un böylesi geniş bir alanda faaliyet göstermesi ruhu bedene bağıml, bedenin tamamına yayılmış bir maddi töz olarak kabul etmesinden kaynaklanır. ${ }^{36}$

Pneuma kavramını merkeze alan Athenaeus, zihinsel hastalıkları bedensel ve ruhsal sağlık arasındaki dengeden hareketle tanımlayarak her iki alandan kaynaklı bir etkileşim ortaya çıkarmaya çalışır. ${ }^{37}$ Ancak onun felsefesinde rasyonel faaliyetlerin tamamının bedensel egzersizlerden hareketle inşa edildiği unutulmamalıdır. Buna göre rasyonel faaliyetlerin yoğun bir şekilde yaşandığı matematik ve felsefe gibi alanlarda sağlıklı bir etkileşimin oluşması için güçlü bir ruhun yanında sağlıklı bir bedene de ihtiyaç duyulmaktadır. Böyle bir sürecin oluşması ise bedensel sağlığın teminatı olan ruhsal ve bedensel egzersizlerle mümkün olur. Ancak Athenaeus, ruh ile bedenin egzersizlerini birbirinden ayırır. 0, ruhun egzersizini araştırma, inceleme ve bağlantı kurma şeklinde kategorize ederken bedenin egzersizlerini emek harcamak ve çaba sarf etmek olarak ifade eder. Bu noktada Athenaeus, her ne kadar zihinsel ve bedensel aktiviteleri birbirinden bağımsız karakterize etse de nihayetinde her ikisinin aynı etkiyi ortaya çıkardığını iddia eder. Nitekim Antik Yunan düşüncesinin son döneminde tıp alanında ruh/beden düalizmine dair genel eğilim, -Athenaeus'un görüşlerine paralel olarak- hastalıkların fizyolojik kökene sahip olduğu şeklindedir. Sözgelimi Athenaeus'un melankoli hastalığını sıcak, soğuk, ıslak ve kuru olarak ${ }^{38}$ adlandırılan birincil niteliklerin ideal oranda karıştırılmamasından kaynaklı görmesi yukarıdaki anlayışın bir tezahürü olarak kabul edilebilir. Daha son-

\footnotetext{
35 Nutton, Ancient Medicine, s.203.

${ }^{36}$ Coughlin, "Athenaeus of Attalia," ss.120-121.

37 İnsandaki dengeye vurgu yapan Athenaeus'un böyle bir düşünceyi, hastalığı insandaki doğal dengenin bozulması șeklinde ifade eden Hipokrates'ten aldığı ileri sürülebilir. Bektaş Murat Yalçın ve diğerleri, “Anadolu Tıp Tarihi: Bölüm I," Türkiye Aile Hekimliği Dergisi 20:1 (2016), s.39.

${ }^{38}$ Hipokrates' in de benzer anlayışa sahip olduğu söylenebilir. Nitekim o, evrendeki tüm hayvanlar ile insanların ateş ve sudan oluştuklarını, ateşin sıcak ve kuru; suyun da soğuk ve ıslak olanı temsil ettiğini savunur (Yalçın ve diğerleri, "Anadolu Tıp Tarihi: Bölüm I," s.39). Ona göre bu canlıların bedenleri, tek bir maddeden oluşmasına rağmen ruhun veyahut psuchenin ateş ve suyla karışımından oluşur. Lloyd, "Pneuma between Body and Soul," ss.139-140.
} 
ra Athenaeus'un öğrencileri, böylesi bir karışımda ıslak ve sıcak nitelikleri benimsememişlerdir. ${ }^{39}$

Athenaeus'a benzer bir görüșü benimseyen Galen, sıcak, soğuk, sslak ve kuru şeklinde tezahür eden dört elementin herhangi bir bedende yalın bir halde bulunmadığını iddia eden düşünürleri eleștirir. Ona göre bitki, hayvan ve insanda var olan bu dört element, sözgelimi su ile toprağın birleşmesinden bitkileri oluşturan bir niteliğe sahiptir. Bu noktada bu niteliğin beden ve güçlerle nasıl bir ilişki içerisinde olduğu sorgulanması gereken bir husustur. Bu hususta Athenaeus, bedenin algısal açıdan belirgin olmasına rağmen güçlerinin aynı açıklığa sahip olmadığını ileri sürer. Bu durum, filozof-hekimin hastalık ile sağlığa dair önerdiği ilaçlar ve besinlerin neye iyi geldiğini bilmesinin yanında onların hangi maddelerden dolayı böyle bir etkiyi gösterdiklerini de bilmesi gerektiğini ortaya koyar. Böylesi bir gereklilik, tıp ve felsefenin yanında fiziğin de önemini gösterir. Ancak Hankinson, Athenaeus'un bedenler ile onların nitelikleri arasında ayrım yapmada yeterli başarıyı elde edemediğini iddia eder. Buna karşın Aristotelesçi ${ }^{40}$ bir yapıyı benimseyen Galen, fayda derecesine bakmaksızın bedenler ile nitelikleri arasında zorunlu bir bağın varlığını kabul eder. Bu noktada Athenaeus'un böylesi bir zorunluluğu dikkate almadan nitelikleri nasıl temellendireceği, sorgulanması gereken bir husustur. Bu hususa dikkat çeken Galen, niteliklerinden bağımsız bir bedende vücut ısısının mükemmel bir sıcaklık olduğunun somut bir şekilde izah edilmesini mümkün görmez. ${ }^{41}$

\footnotetext{
${ }^{39}$ Sıcak ve ıslak olanı sağlığın, diğer tüm karışımları ise hastalığın işareti kabul eden Athenaeus'un melankoliyi diğer hastalıklardan farklı bir yere koymadığı görülür. Zira soğuk ve kuru olanın karışımı olduğu için melankolinin bir hastalık olarak benimsenmesi anlaşılır bir husustur. Ancak bu husus, zihinsel bozukluk (phrenitis) açısından ele alındığında Athenaeus'tan ziyade öğrencilerinin görüşleri ön plana çıkmaktadır. Bu hastalığa yakalananları kronik olup olmamalarına göre ayıran bu öğrenciler, kronik hastalıklarda ısıtılan cam kapları bedenin belli yerlerine uygulayıp enerji akışını sağlayarak tedavi ederlerken kronik olmayan hastalıklarda hastanın saçlarını kazıyıp soğutucu etkisi olan bitkileri sürerek çözüm üretmeye çalışmışlardır. Aslında bu metot, o dönemde ateşi azaltmak için kullanılan sıradan bir yöntemdir. Athenaeus'un öğrencileri tarafından bu yöntemin böyle bir amaca hizmet edeceği bilinmektedir. Hatta böyle bir düşüncenin ateşi, sıcak ve kuru olanın karışımından ortaya çıkan şeklinde ifade etmesi, Athenaeus'un görüşleriyle uyumlu olduğunu göstermektedir. Coughlin, "Athenaeus of Attalia," ss.116-120.

${ }^{40}$ Flemming, Aristoteles'in beden ve niteliklerine dair düşüncelerinde iki yönden yanıldığını iddia eder. Bunlardan ilki, bedenin oluşum sürecinde niteliklere nedensel açıdan bir öncelik atfetmesidir. İkincisi, ruhumuzda var olan karakterlerin uyumlu bir birlikteliğini sağlayan "maharetli gücü” (the skilful power) önemsememesidir. Rebecca Flemming, "Demiurge and Emperor in Galen's World of Knowledge," Christopher Gill ve diğerleri (ed.), Galen and the World of Knowledge (New York: Cambridge University Press, 2009) içinde, s.77.

41 Robert James Hankinson, "Philosophy of Nature," Robert James Hankinson (ed.), The Cambridge Companion to Galen (New York: Cambridge University Press, 2008) içinde, ss.215-216.
} 
Beden ve nitelikleri arasındaki ilişkide birbirinden farklı görüşler ortaya koyan Athenaeus ile Galen'in insan sağlığı söz konusu olduğunda en azından vücut ısısının önemi noktasında bir birlikteliğe sahip oldukları söylenebilir. Buna göre insan sağlığının temel bileșenleri olan ruhsal ve bedensel egzersizlerin ${ }^{42}$ temel hedefi, insanın vücut ısısını artırmaktır. Nitekim Athenaeus, Galen ve Hipokrates'in de böyle bir hedeften hareket ettikleri ve dolayısıyla herhangi bir hastayı duyusal ve zihinsel açıdan rahatlatmak amacıyla vücut ısısını artıracak egzersizleri tavsiye ettikleri görülür. Buna ilaveten Athenaeus'un vurguladığı diğer bir husus, düzenliliktir. ${ }^{43}$ Ona göre sağlıklı bir diyetin ortaya çıkması için zihinsel ve bedensel egzersizlerin bir düzen veya standart içerisinde sürdürülebilirliği oldukça önemli bir husustur. Ancak bu noktada diyet yapmamiza neden olan problemin irademiz dışında bir zorunluluğa sahip olmaması, diğer ifadeyle kontrol altına alınabilir olması gerekmektedir. Zira söz konusu problemin teşekkülünde bedensel etkinin yanında iradesel bir faktörün de varlığı bilinen bir durumdur. Hekimlerin diyete dair herhangi bir egzersiz programı hazırlarken hastanın zihinsel ve iradi özelliklerini de göz önünde bulundurmaları, böylesi bir durumun sonucu olarak okunmalıdır. Aslında diyet konusunda ruhsal ve bedensel niteliklerin dikkate alınması, geçmişten intikal eden bir geleneğin sonucu olarak ele alınmalıdır. Böyle bir iddianın sadece Hipokrates üzerinden değil de Ksenophon gibi diğer düşünürlerin de dikkate alındığ bir süreci ihtiva ettiği unutulmamalıdır.44

\section{Sonuç Yerine}

Antik dönemde Antalya'da yaşamış olan Athenaeus'un ruh/beden düalizminde Stoacı bir yaklaşımı benimsediği, felsefede doğa filozoflarından itibaren önemli bir yer tutan pneuma kavramını ilahi bir kaynaktan ziyade insani yaşamın bir tezahürü olarak yorumladığı görülür. Onun bu yorumu, ruh/beden düalizminde daima ruhun üstünlügünü kabul eden Platoncu ve

\footnotetext{
${ }^{42}$ Platon, egzersiz hususunda her bir insandan ziyade bütünü kapsayacak bir egzersiz programının uygulanmasını daha anlamlı bulur. Mark John Schiefsky, Hippocrates on Ancient Medicine (Leiden \& Boston: Brill, 2005), s.363. Nitekim Athenaeus'un ruhsal ve bedensel egzersizlerin hem vücut ısısını artırması hem de bir düzenlilik içerisinde gerçekleşmesini vurgulaması, aslında insan açısından genel bir yaklaşıma sahip olduğunu göstermektedir.

${ }^{43}$ Athenaeus, bedenin sağlıklı olmasında düşüncenin yanında duyguları kontrol eden alıșkanlıkların da belirleyici olduğunu ileri sürer. Diğer ifadeyle sağlıklı bir diyet için ilk olarak alışkanlıkların değiștirilmesi ve daha sonra bu sürecin düzenli hale getirilmesi gerekmektedir. Athenaeus'un böylesi bir süreçte hastayı duygusal olarak kötü durumlara sevk edecek bir diyetten uzak durduğu belirtilmelidir. Burada vurgulanmak istenen asıl husus, uygulanan diyetin hastanın hem duygusal yönünü rahatlatacak bir düzeyde olması hem de düzenliliğin sağlanmasıyla alışkanlık haline getirilmesidir. Coughlin, "Athenaeus of Attalia," ss.128-129.

${ }^{44}$ Coughlin, "Athenaeus of Attalia," ss.120-122.
} 
Aristotelesçi yaklaşımlardan farklı olarak bedenin merkezde olduğu bir anlayışı benimsediğini ortaya koymaktadır. Zira Athenaeus'un insanın psikolojik hastalıklarının kaynağını bedensel problemlerde görmesi ve tedavi yönteminde bedeni önceleyen bir tavır takınması, ruhtan ziyade bedeni önemsediğini göstermektedir.

Athenaeus'un erdemli bir hayatın yaşanmasında etkili olan ruhsal ilerlemeden psikolojik açıdan değerlendirilen diyetin bedensel egzersizlerle elde edildiğine varıncaya kadar pek çok anlayışı indirgemeci bir yaklaşımla incelemesi, Helenistik dogmatizm, Hipokrates'in düşünceleri ile Stoa felsefesinden etkilendiğini göstermektedir. Buna ilaveten Athenaeus'un bedensel olanı ön plana çıkarması Platon tarafından inşa edilen, zaman içerisinde Aquinolu Thomas (1225-1274), Descartes (1596-1650), Kant (1724-1804) ve Hegel (1770-1831) ile sistematik bir hale dönüșen Platoncu düşüncenin kalın çizgilerle olmasa da Protagoras'tan itibaren daima eleştiriye tabi tutulan bir yapı üzerinden varlığını devam ettirdiğini göstermektedir. Şöyle ki Platoncu düşünce, ruhsal olanı önceleyen tavrından ötürü felsefe tarihinde evrensel, mutlak, sabit ve değişmez bir anlayışı hakim kılarken Athenaeus'un bedeni merkeze alması çağdaş felsefede ortaya çıkan yerel, olumsal, değişken ve farklılaşan anlayışların antik döneme kadar izlerinin sürülebileceğini göstermektedir.

Tüm bunlardan hareketle, Athenaeus'un ruhsal ve bedensel hastalıkları tedavi etmek için her iki alanı da kapsayan egzersizleri önemseyerek hem insan sağlığını sistematik bir yapı içerisinde tutmaya hem de ruh/beden dengesini korumaya çalıştığı söylenebilir.

\section{KAYNAKÇA}

Akyüz, Gülseren ve Merve Akdeniz Leblebiciler. "Otonom Sinir Sistemi Anatomisi ve Değerlendirilmesi," Türkiye Fiziksel Tip ve Rehabilitasyon Dergisi 58:1 (2012), ss.1-5.

Aristoteles. Ruh Üzerine. Terc. Zeki Özcan. Ankara: Sentez Yayınları, 2014.

Arslan, Ahmet. İlkçağ Felsefe Tarihi 3: Aristoteles. İstanbul: İstanbul Bilgi Üniversitesi Yayınları, 2007.

Arslan, Ahmet. İlkçağ Felsefesi Tarihi 1: Sokrates Öncesi Yunan Felsefesi. İstanbul: İstanbul Bilgi Üniversitesi Yayınları, 2006.

Aurelius, Marcus. Kendime Düşünceler. Terc. Ceyda Eskin. İstanbul: Oda Yayınları, 2009.

Cevizci, Ahmet. Felsefe Tarihi. İstanbul: Say Yayınları, 2017.

Cevizci, Ahmet. Metafiziğe Giriş. İstanbul: Paradigma Yayınları, 2001. 
Coughlin, Sean. "Athenaeus of Attalia on the Psychological Causes of Bodily Health," Chiara Thumiger ve Peter Singer (ed.), Mental Illness in Ancient Medicine (Leiden \& Boston: Brill, 2018) içinde, ss.109-142.

Eijk, Philip J. van der. Medicine and Philosophy in Classical Antiquity. New York: Cambridge University Press, 2005.

Flemming, Rebecca. "Demiurge and Emperor in Galen's World of Knowledge," Christopher Gill, Tim Whitmarsh ve John Wilkins (ed.), Galen and the World of Knowledge (New York: Cambridge University Press, 2009) içinde, ss.5984.

Galen. Selected Works. Ed. Peter N. Singer. New York: Oxford University Press, 1997.

Hankinson, Robert James. "Evidence, Externality and Antecedence: Inquiries into Later Greek Causal Concepts," Phronesis 32:1 (1987), ss.80-100.

Hankinson, Robert James. "Philosophy of Nature," R. J. Hankinson (ed.), The Cambridge Companion to Galen (New York: Cambridge University Press, 2008) içinde, ss.210-241.

Herophilus. The Art of Medicine in Early Alexandria. Ed. Heinrich von Staden. New York: Cambridge University Press, 1989.

Johnston, Ian. Galen: On Diseases and Symptoms. New York: Cambridge University Press, 2006.

Lloyd, Geoffrey. "Pneuma between Body and Soul," The Journal of the Royal Anthropological Institute 13 (2007), ss.135-146.

Nutton, Vivian. Ancient Medicine. Londra \& New York: Routledge, 2013.

Platon. Phaidon. Terc. Ahmet Cevizci. Ankara: Gündoğan Yayınları, 1995.

Platon. Philebos. Terc. S. Esat Siyavuşgil. İstanbul: MEB Yayınları, 1997.

Platon. Timaios. Terc. Furkan Akderin. İstanbul: Say Yayınları, 2015.

Preus, Antony. Historical Dictionary of Ancient Greek Philosophy. Toronto: The Scarecrow Press, 2007.

Rocca, Julius. Galen on the Brain: Anatomical Knowledge and Physiological Speculation in the Second Century AD. Leiden \& Boston: Brill, 2003.

Runes, Dagobert D. The Dictionary of Philosophy. New York: Philosophical Library, 1942.

Schiefsky, Mark John. Hippocrates on Ancient Medicine. Leiden \& Boston: Brill, 2005.

Shields, Christopher John. Aristotle. New York: Routledge, 2007.

Yalçın, Bektaş Murat, Mustafa Ünal, Hasan Pirdal ve Yasin Selçuk. "Anadolu Tıp Tarihi: Bölüm I,” Türkiye Aile Hekimliği Dergisi 20:1 (2016), ss.33-44. 
